\title{
Research Into Care Quality Criteria for Long-Term Care Institutions
}

\author{
Wen-Liang Wang • Hong-Jer Chang* • An-Chi Liu** • Yu-Wen Chen***
}

\begin{abstract}
The purpose of this paper was to determine the criteria that reflect the quality of care provided by long-term care institutions. Research was conducted using a two-step procedure that first utilized the SERVQUAL model with Fuzzy Delphi Method to establish the proper criteria by which service quality could be measured. A total of 200 questionnaires were mailed to expert respondents, of which 89 were returned and 77 deemed valid for use in this study. We then applied the Multi-Criteria Decision Making Process to determine the degree of importance of each criterion to long-term care institution service quality planning work. Secondly, 200 questionnaires were distributed and 74 valid responses were returned. Based on the 5 SERVQUAL model constructs, this study found 17 of the 28 criteria, to be pertinent to nursing care quality, with those in the Responsiveness and Empathy domains being the ones most critical.
\end{abstract}

Key Words: long-term care institution, service quality, SERVQUAL model, multi-criteria decision making analysis.

\section{Introduction}

Statistics compiled by the Social Service Division of Taiwan's Ministry of the Interior (MOI) indicate that Taiwan experienced a major demographic transition during the mid-1980's characterized by rapid growth in percentage of senior citizens in the population. By 1993, senior citizens (defined as those 65 years of age and older) accounted for $7 \%$ of the total population, making Taiwan an "aging society" as defined by the World Health Organization. The percentage of senior citizens was roughly $10.0 \%$ at the end of 2006 and is projected to reach $20.04 \%$ by 2027 (Council for Economic Planning and Development, Executive Yuan, 2005). Population aging inevitably places a burden on long-term healthcare systems, given that the primary needs of senior citizens fall into the activities of daily living (ADL) and instrumental activities of daily living (IADL) care categories. The magnitude of the need for long-term care is reflected in the number of elderly classified as dependent. The percentage of senior citizens with at least one chronic illness reached a historic high of $65 \%$ several years ago, with one out of ten in need of long-term care (Wang \& Chen, 2004). As a result, the past decade has witnessed a tremendous expansion of long-term institutional and community-based care services. In the midst of service expansion, a number of nursing home disasters have drawn public attention to issues related to quality assurance. Quality assurance constitutes merely one part of long-term care issues in this country. The broader picture must address approaches to designing a sound system that involve the public and private sectors in order to meet the urgent needs of the dependent elderly (Wu \& Chuang, 2001).

The need for care has come to be perceived as an inviolable human right with calls by an increasing number of experts to implement a comprehensive system of care (Hung \& Kao, 2004; Li, 1999). As the long-term care needs of the dependent elderly draws an increasing amount of healthcare resources, family care has suffered in terms of resources and availability. The decline has been attributed to a number of factors, including the prevalence of

DS, Assistant Professor, Department of Information Management, Chung Hua University, Hsinchu City; *PhD, Assistant Professor, Graduate Institute of Long-Term Care, National Taipei College of Nursing; **MBA, Lecturer, Department of Marketing \& Logistics Management, Yu Da College of Business; ***PhD, Associate Professor, Department of Social Work, National Taiwan University.

Received: February 1, 2007 Revised: May 14, 2007 Accepted: September 17, 2007

Address correspondence to: Wen-Liang Wang, No. 707, Wu Fu Rd. Sec. 2, Hsinchu City 30012, Taiwan, ROC. Tel: 886(3)518-6529; Fax: 886(3)518-6546; E-mail: abewang@chu.edu.tw 
the nuclear family, the increasing participation of women in the labor market, and the increasing prevalence of elderly living on their own. With the limited availability of formal community-based healthcare, an increasing number of elders are electing to live in nursing homes, particularly those located near to their own neighborhood (Li, Pong, \& $\mathrm{Wu}, 2004)$. Neighborhood-based nursing homes, typically small-scale, homey, and easily set up, have enjoyed strong growth (Chiou, Yang, \& Chen, 2004; Wu \& Chuang, 2001). The initially lax attitude on the part of the government toward community-based in terms of service quality and safety has been increasingly replaced by formalized rules and inspections since 1998, due to several high-profile incidents. While quality assurance has today become the primary concern of care provision, a review of the literature has generated few studies on this subject. This study intends to fill the void in the literature.

The purpose of this study is twofold. The first is to employ a standard of quality care scale as a tool to extract several dimensions identified by a number of expert respondents providing care to senior citizens in community-based nursing homes. The dimensions and items extracted were then administered to the same group of respondents as well as to residents' family members in order to evaluate their general perceptions of quality of care in long-term care institutions. This paper served as an illustration of how the tool might be useful when conducting quality evaluations.

\section{Literature Review}

\section{Aging in place}

In the realm of long-term care, "aging in place" has become a guidepost for planning and constructing a system where care takes place in a setting as natural, homely, and near to the care recipient's original residence as possible. The idea has recently caught on among Taiwan central government social and health departments, which have adopted it as a core objective of policy initiatives (Chiou et al., 2004). Jamieson (1996) stated that, aging in place, when supported with essential in-home and community-based care (both formal and informal), may permit senior citizens to live with dignity, autonomy, and self control and enhance their quality of life (cited in Wu \& Chuang, 2001). However, implementation of this idea currently lags far behind policy intent. Women's participation in the labor market, prevalence of the nuclear family, and an increasing number of elderly living on their own combine to threaten the supply of informal care, which is a primary component of aging in place. The lack of a social security system and long-term care insurance has worked to limit the ability of the dependent elderly to access services (Wu \& Chuang, 2001). A recent plan by the government to expand community-based care availability has gone nowhere due to financial constraints (Wu \& Lin, 1999).

Community-based small nursing homes, with homely settings and neighborhood locations, have gained increasing momentums and are today perceived fitting in well with the ideals of aging in place. In the midst of its expansion, issues of care quality came starkly to the fore when a dozen elderly residents were killed in a fire at an unlicensed home. The incidence prompted the government to tighten regulations, including licensing requirement. A licensing backlash has nevertheless almost stifled official efforts to regulate the industry when un-licensed providers threatened to put elderly residents on the street. Regulators eventually gave in to the demand of providers by loosening up licensing requirements, which subsequently saw a rush of license applications in 1998. As the majority of homes completed their licensing process over the past decade, problems loomed large. For experts, regulators, and consumers, issues of care quality continue to be of primary concern.

\section{Nursing home care quality}

While the subject of nursing home care quality has been widely researched in recent years, there remains no consensus on quality care indicators or criteria. A committee on nursing home regulations in the United States concluded in the book, "Improving the quality of care in nursing homes (1986)", that the present regulatory system for nursing homes is inadequate, and stated that what is needed is not more, but better regulation. Better regulation should include a clear delineation of crucial indicators for quality care. As for monitoring and evaluating care quality, it is better to employ multiple-dimension than single-dimension indicators. Indicators for multiple-dimension quality care nonetheless vary from researcher to researcher. Among the indicators, Finnema, Lange, Dröes, Ribbe, and Tilburg (2001) suggested that there is room for improvement in the communication by nursing home staff with family members in order to improve care quality. Rantz et al. (1999) measured nursing home care quality based on the seven dimensions of central focus, interaction, milieu, environment, individualized care, staff, and safety. Rantz, 
Zwygart-Stauffacher, and Flesner (2005) adopted a rather complicated approach that used a 47-item instrument with 7 factors entitled "Observable Indicators of Nursing Home Care Quality Instrument" (OIQ): care delivery, grooming, interpersonal communication, environment (access, basics, homelike), and odors. As to the sources of information on quality care, it would be plausible to obtain perspectives on a set of indicators from a broad base. For instance, Duffy, Duffy, and Kilbourne (2001) evaluated service quality in nursing homes from the point of view of residents, family members, and administrators. This study had the advantage of employing a multi-criteria decision-making model to extract indicators of nursing home care quality from the perspectives of a multi-disciplinary group of experts and consumers.

\section{SERVQUL model}

Service quality may be defined as assessing, confirming, and meeting the needs of clients (Deming, 1982). It connotes the extent to which provided services reach a certain standard or exceed client expectations to eventually earn client respect and loyalty. This study employed the SERVQUAL model to analyze responses from experts and consumers. The model's original service dimensions were determined by Parasuraman, Zeithaml, and Berry (1985), with subsequent refinements and industry-specific adaptations. Parasuraman, Zeithaml, and Berry (1988) augmented the SERVQUAL (Service Quality) model to differentiate between service quality and customer satisfaction, as the two terms were used interchangeably in the originally proposed model to describe the process in which customers assessed service quality by comparing the services they received with those they preferred or expected. The SERVQUAL model, frequently used as a diagnostic technique to identify an organization's service quality strengths and weaknesses, has been used widely to measure service quality in many fields. For example, Chou, Chen, Woodard, and Yen (2005) used SERVQUAL to evaluate quality disconfirmation of nursing services.

The SERVQUAL model by Parasuraman et al. (1988) consists of the following five constructs:

(1) Tangibles - physical facilities, equipment, and appearance of personnel.

(2) Reliability - ability to perform the promised service accurately and dependably.

(3) Responsiveness - willingness to help customers and provide prompt service.
(4) Assurance - knowledge and courtesy of employees and their ability to convey trust and confidence.

(5) Empathy - caring and individualized attention to customers.

In general, SERVQUAL is a 22 -item instrument that addresses multiple service quality elements falling into the 5 constructs noted above. This paper modified the items based on the opinions of experts, who included college professors, nurses, occupational therapists, physical therapists, nursing home administrators, and activity specialists and generated 28 indicators pertaining to the 5 constructs. This study also took family member perspectives into account by integrating other techniques into SERVQUAL. The purpose was to find out what the customers really expect and extract major criteria for quality care from their expectations. These techniques are presented as follows.

\section{Fuzzy Delphi Method}

The Delphi method pertains to a technique used to predict as well as to make collective decisions (Noorderhaven, 1995). The method is a way of reaching consensus through continuous reckoning with a specific target of prediction. It has the advantage of combining collective wisdom with individual expertise.

The Fuzzy Delphi Method (FDM) combines the traditional Delphi method with fuzzy theory. It has been employed for collective decision-making purposes and provides a way around a fuzzy problem when trying to reach an expert consensus. To support the formulation of collective decisions, this study opted for the triangular membership function and fuzzy theory. The selection of this option is justifiable, given that the number of experts suitable for collective decision-making range from five to seven (Robbins, 1994). The triangular membership function works well with a small group of experts trying to reach a consensus. This study utilizes FDM for the initial step of selecting preliminary quality care indicators. The use of fuzzy theory both solves the problem of lack of unanimity among experts and reduces the need to administer questionnaires multiple times to collect expert opinions. The next step involves applying statistical analysis to select more objective indicators than possible through previous procedures.

\section{Similarity function}

The arrival at a consensus by experts constitutes a crucial step in making collective decisions. Ways of 
reaching consensus vary. In many cases, geometric and mathematic means are employed to represent a synthesis of expert opinions. The use of means has its drawback when outliers are plentiful, resulting in a failure of its synthetic function. When opinions are dispersed, consensus is consequentially unattainable and the outcome falls short of accuracy.

Facing the shortfalls of traditional method in reaching consensus, Hsu and Chen (1996) proposed the Similarity Aggregation Method (SAM) as a solution to the problem. The method provides a way to synthesize the fuzzy values of expert opinions by employing a similarity function to calculate the degree of agreement between any pair of experts. Obtained agreement degrees can then be used to construct an agreement matrix.

\section{Fuzzy Analytic Hierarchy Process}

The Analytic Hierarchy Process (AHP), developed by Thomas L. Saaty $(1977,1980)$, is a multi-criteria decision-making method that can be employed to solve problems with multiple criteria under uncertain circumstances. Ciou, Chang, Hung, and Tam (2006) applied AHP to discern the viewpoints of personnel in various positions at a teaching hospital regarding priority factors to consider when implementing a responsibility center system. However, AHP has been found to be incapable of dealing with problems of uncertainty in decisionmaking situations. Its major limitation lies in its lack of precision. The weighting method employed by Saaty (1980) is of little use when the concept of fuzziness is involved. The revised version utilizes fuzzy theory and fuzzy numbers to solve the problems of fuzziness. The new version combines AHP with fuzzy theory to become a Fuzzy Analytic Hierarchy Process (FAHP) by applying triangular fuzzy numbers to form a pairwise comparison matrix. Buckley (1985) applied the fuzzy set theory to depict decision-maker fuzziness when making decisions in order to more accurately express the opinion of each and enhance decision-making quality. It has been applied to situations of uncertainty where decision-making can be evaluated against multiple methods and indicators (Hsu, 1998). This study used the Similarity Aggregation Method (SAM) developed by Hsu and Chen (1996) to aggregate the weighted values given to each indicator by experts and residents' family members. Through FAHP and fuzzy operations, the fuzzy weights for each hierarchical criterion can be generated.

\section{Methods}

This study employed the SERVQUAL model in its examination of long-term care institution care quality criteria. A convenience sample of 200 experts was drawn from a mailing list provided by the Long-Term Care Institution Associations of Taipei City, Hsinchu City and County, and Taichung City and County. Among the 77 experts who responded and agreed to participate in the study were many long-term care professionals, including college professors, nurses, occupational therapists, physical therapists, nursing home administrators, and activity specialists. The response rate was $38.5 \%$. A note of caution was in order here: as data collection and analysis methods employed in this study were not statistical in nature, findings are not intended to be generalized the larger population. By tapping expert opinions, the methods demanded a sample not so much for its representative nature as for the diversity of opinions which might be generated. Therefore, a sample of 77 experts from diverse disciplines and institutions could be hoped to approximate opinion saturation. A Fuzzy Delphi questionnaire was constructed based on the SERVQUAL model developed by Parasuraman et al. (1988) with five constructs, including tangibles, reliability, responsiveness, assurance, and empathy, and twenty-eight factors (see Table 1). Respondents were requested to rate or weigh the degree of importance for each construct and item. The score for each item was obtained and rank ordered to provide a system of rating for care quality in the long-term care institution under consideration. As mentioned previously, the framework for constructing the questionnaire for this study was adapted from the SERVQUAL model to measure perceived service quality. An analysis of baseline measures for the questionnaire, coupled with a review of previous studies published in the literature and a summary of expert opinions, generated twenty-eight indicators against which long-term care institution care quality should be evaluated. The second step was then initiated using SAM and FAHP. In this step, the obtained dimensions and items extracted during the first step were then administered to the same group of respondents as well as residents' family members to evaluate perceived longterm care institution care quality. A total of 200 questionnaires were distributed and 74 valid questionnaires were returned. The importance of each criterion to service quality planning was then determined. 
Table 1.

Indicators of Quality Care for Long-Term Care Institution

\begin{tabular}{|c|c|}
\hline Item & Indicators \\
\hline Tangibles & $\begin{array}{l}\text { 1. They should have up-to-date equipment and facility. } \\
\text { 2. Physical facilities should be visually appealing. } \\
\text { 3. Staffs should be well dressed and appear neat. } \\
\text { 4. The appearance of the physical facilities of the long-term care institution should be in keeping with the } \\
\text { type of services provided. } \\
\text { 5. Long-term care institutions can provide recreational activities according to the needs of residents. } \\
\text { 6. Fees charged by long-term care institution are reasonable. }\end{array}$ \\
\hline Reliability & $\begin{array}{l}\text { 7. When a long-term care institution promises to do something by a certain time, they should do so. } \\
\text { 8. When residents have problems, long-term care institution staffs should respond with a sympathetic and } \\
\text { reassuring attitude. } \\
\text { 9. Long-term care institutions are well-known for their reliability in providing care. } \\
\text { 10. Long-term care institution should provide their service on schedule as promised. } \\
\text { 11. Long-term care institution should keep accurate records. }\end{array}$ \\
\hline Responsiveness & $\begin{array}{l}\text { 12. Long-term care institution should tell residents what kind of services will be provided. } \\
\text { 13. When a resident needs assistance, staffs can be called upon immediately. } \\
\text { 14. Staffs can respond promptly to any incident. } \\
\text { 15. Staffs should be able to answer the questions raised by family members over the phone. } \\
\text { 16. Staffs are highly motivated to provide services and care. } \\
\text { 17. Staffs are not too busy to respond to the needs of residents. }\end{array}$ \\
\hline Assurance & $\begin{array}{l}\text { 18. Staffs are trustworthy, letting residents feel secure. } \\
\text { 19. Staff behavior will reflect positively on the long-term care institution. } \\
\text { 20. Staffs are polite, enthusiastic, and cordial towards residents. } \\
\text { 21. Residents will feel secured when taking care by the staffs. } \\
\text { 22. Staffs are equipped with adequate knowledge and skills. }\end{array}$ \\
\hline Empathy & $\begin{array}{l}\text { 23. Long-term care institution will provide care by attending to different resident. } \\
\text { 24. Staffs can be called upon any time by the residents. } \\
\text { 25. Staffs provide care differentially by attending to the different needs of residents. } \\
\text { 26. Services provided by the long-term care institution are in congruence with the needs of their residents. } \\
\text { 27. In any dispute involving care, the institution would give top priority to safeguarding the rights and } \\
\text { dignities of residents. } \\
\text { 28. Staffs are aware of residents' individual needs. }\end{array}$ \\
\hline
\end{tabular}

\section{Results}

Findings shown in Table 2 indicate that among the 28 indicators of quality designed into SERVQUAL model, 17 were identified as crucial to long-term care institution care quality evaluations. This result was used to construct the FAHP framework for weighing and ranking purpose.

\section{Synthesis of Expert Opinions and Weighting of FAHP Indicators}

The fourth construct (D, Reliability) was used to illustrate the synthesis of expert opinions and weighting proce- dures (shown in Table 3), where C represents "Construct"; E "Expert"; D1, D2, and D3 the first, second, and third indicators, respectively, of construct D; and E1, E2, ..., E74 experts 1 through 74, respectively. Weighting procedures were performed by assigning a fuzzy number evaluated by each expert into the matrix. The element on each cell is the ratio obtained by evaluating between any two indicators by each expert. For instance, the first fuzzy number, $\widetilde{2}$, represents that the importance of D1 is twice as much as D2, as evaluated by E1. However, if the importance of D2 is twice as much as D1, then the fuzzy number can be written as the reciprocal form, i.e. $\widetilde{2}^{-1}$, as shown in the second row, third column of Table 3. 
Table 2.

The Selection of Care Quality Indicators via FDM (Fuzzy Delphi Method)

\begin{tabular}{|c|c|c|c|c|c|}
\hline Dimension & Indicator & Minimum & Means & Maximum & $\begin{array}{l}\text { Defuzzi- } \\
\text { fication }\end{array}$ \\
\hline \multirow[t]{2}{*}{ Tangible } & They should have up-to-date equipment and facilities. & 5 & 9.05 & 10 & 8.02 \\
\hline & $\begin{array}{l}\text { Long-term care institution can provide recreational activities } \\
\text { according to the needs of their residents. }\end{array}$ & 5 & 9.00 & 10 & 8.00 \\
\hline \multirow[t]{2}{*}{ Reliability } & $\begin{array}{l}\text { Long-term care institutions are well-known for their } \\
\text { reliability in providing care. }\end{array}$ & 6 & 8.61 & 10 & 8.20 \\
\hline & Long-term care institution should keep accurate records. & 6 & 8.69 & 10 & 8.23 \\
\hline \multirow[t]{4}{*}{$\begin{array}{l}\text { Respon- } \\
\text { siveness }\end{array}$} & $\begin{array}{l}\text { When a resident needs assistance, staffs can be called upon } \\
\text { immediately. }\end{array}$ & 7 & 9.32 & 10 & 8.77 \\
\hline & Staffs can responds promptly to any incident. & 5 & 9.42 & 10 & 8.14 \\
\hline & Staffs are highly motivated to provide services and care. & 5 & 9.05 & 10 & 8.02 \\
\hline & Staffs are not too busy to respond to the needs of residents. & 5 & 9.00 & 10 & 8.00 \\
\hline \multirow[t]{3}{*}{ Assurance } & Staffs are trustworthy, letting residents feel secure. & 6 & 9.10 & 10 & 8.37 \\
\hline & Staffs are polite, enthusiastic, and cordial towards residents. & 7 & 9.04 & 10 & 8.68 \\
\hline & Staffs are equipped with adequate knowledge and skill. & 5 & 9.20 & 10 & 8.06 \\
\hline \multirow[t]{6}{*}{ Empathy } & $\begin{array}{l}\text { Long-term care institution will provide care by attending to } \\
\text { different resident. }\end{array}$ & 6 & 8.93 & 10 & 8.31 \\
\hline & Staffs can be called upon any time by the residents. & 7 & 9.16 & 10 & 8.72 \\
\hline & $\begin{array}{l}\text { Staffs provide care differentially by attending to the different } \\
\text { needs of residents. }\end{array}$ & 6 & 8.90 & 10 & 8.30 \\
\hline & $\begin{array}{l}\text { Services provided by long-term care institution are in } \\
\text { congruence with the needs of their residents. }\end{array}$ & 7 & 9.10 & 10 & 8.70 \\
\hline & $\begin{array}{l}\text { In any dispute involving care, the institution would give top } \\
\text { priority to safeguarding the rights and dignities of residents. }\end{array}$ & 6 & 9.14 & 10 & 8.38 \\
\hline & Staffs are aware of residents' individual needs. & 6 & 9.09 & 10 & 8.36 \\
\hline
\end{tabular}

Table 3.

Fuzzy Matrix of Experts' Evaluation Under Construct $D$

\begin{tabular}{|c|c|c|c|c|c|c|c|c|c|c|c|c|c|c|}
\hline $\mathrm{C}$ & E1 & E2 & E3 & E4 & E5 & E6 & E7 & E8 & E9 & E10 & $\ldots$ & $\ldots$ & E73 & E74 \\
\hline D1 & $\tilde{2}$ & $\tilde{2}$ & $\widetilde{3}$ & $\tilde{3}$ & $\tilde{2}$ & $\tilde{1}$ & $\tilde{2}$ & $\tilde{1}$ & $\tilde{4}^{-1}$ & $\tilde{3}^{-1}$ & $\begin{array}{l}\cdots \\
\cdots\end{array}$ & $\begin{array}{l}\cdots \\
\cdots\end{array}$ & $\tilde{1}$ & $\tilde{1}$ \\
\hline )1 & $\widetilde{3}$ & $\tilde{2}$ & $\tilde{4}$ & $\tilde{1}$ & $\tilde{4}$ & $\tilde{2}$ & $\widetilde{3}$ & $\tilde{1}$ & $\tilde{1}$ & $\tilde{3}$ & $\ldots$ & $\ldots$ & $\tilde{1}$ & $\tilde{1}$ \\
\hline $\mathrm{D} 2$ & $\tilde{2}$ & $\tilde{1}$ & $\tilde{2}^{-1}$ & $\tilde{4}^{-1}$ & $\widetilde{3}$ & $\tilde{3}$ & $\tilde{3}$ & $\tilde{1}$ & $\widetilde{5}$ & $\widetilde{5}$ & $\ldots$ & $\ldots$ & $\tilde{1}$ & $\tilde{3}^{-1}$ \\
\hline
\end{tabular}

Note. C represents "Construct", E as "Expert"; D1, D2, and D3, are the first, second, and third indicators of construct D, respectively; E1, E2, ..., E74 represent the first, second, ..., the 74th expert, respectively.

\section{Synthesis of Opinions}

Synthesis of expert opinions was required before weighing was possible. SAM was used to synthesize the scores of any two indicators under one construct by all participants. The procedure generated an objective evaluation by all experts and residents' family members. This can be illustrated by calculating the degree to which the 74 participants reached consensus on the fourth construct. Through fuzzy linguistic variables, the fuzzy matrix for experts' opinions can be obtained as in Table 4. The result of the 
Table 4.

The Result of Fuzzy Pairwise Comparison Matrix by SAM (Similarity Aggregation Method)

\begin{tabular}{lccc}
\hline Item & D1 & D2 & D3 \\
\hline D1 & $(1,1,1)$ & $(1.29,1.52,1.75)$ & $(1.02,1.06,1.15)$ \\
D2 & $(1 / 1.75,1 / 1.52,1 / 1.29)$ & $(1,1,1)$ & $(0.84,0.91,1.01)$ \\
D3 & $(1 / 1.15,1 / 1.06,1 / 1.02)$ & $(1 / 1.01,1 / 0.91,1 / 0.84)$ & $(1,1,1)$ \\
\hline
\end{tabular}

Note. D1, D2, and D3 represent the first, second, and the third indicator under construct D (Assurance), respectively. Numbers in brackets represents the lower, middle, and the upper value of the triangular fuzzy number obtained by SAM.

Table 5.

Ranking of the Importance Degree for the Criteria

\begin{tabular}{|c|c|c|c|c|c|c|c|c|c|c|c|c|c|c|c|c|c|}
\hline \multirow{2}{*}{$\frac{\text { Construct }}{\text { Criterion }}$} & \multicolumn{2}{|c|}{$\begin{array}{c}\mathrm{A} \\
\text { (Tangible) }\end{array}$} & \multicolumn{2}{|c|}{$\begin{array}{c}\text { B } \\
\text { (Reliability) }\end{array}$} & \multicolumn{4}{|c|}{$\begin{array}{c}\text { C } \\
\text { (Responsiveness) }\end{array}$} & \multicolumn{3}{|c|}{$\begin{array}{c}\text { D } \\
\text { (Assurance) }\end{array}$} & \multicolumn{6}{|c|}{$\begin{array}{c}\mathrm{E} \\
\text { (Empathy) }\end{array}$} \\
\hline & $\mathrm{A} 1$ & $\mathrm{~A} 2$ & B1 & B2 & $\mathrm{C} 1$ & $\mathrm{C} 2$ & $\mathrm{C} 3$ & $\mathrm{C} 4$ & D1 & D2 & D3 & E1 & $\mathrm{E} 2$ & E3 & E4 & E5 & E6 \\
\hline Ranking & 17 & 11 & 8 & 3 & 6 & 1 & 15 & 14 & 4 & 16 & 13 & 10 & 9 & 6 & 4 & 2 & 12 \\
\hline
\end{tabular}

ranking of the importance degree for criteria is shown in Table 5, which shows the ranking of importance of each criterion after defuzzyfication and normalization. The top six criteria with seven indicators are: "Staffs can respond promptly to any incident"; "In any dispute involving care, the institution would give top priority to safeguarding the rights and dignities of residents"; "Long-term care institution should keep accurate records"; "Staffs are trustworthy, letting residents feel secure"; "Services provided by the long-term care institution are in congruence with the needs of their residents"; "When a resident needs assistance, staffs can be called upon immediately" and "Staffs provide care differentially by attending to the different needs of residents." The previous represent the most important service quality criteria that respondents perceived as needing to be improved immediately.

\section{Discussion and Conclusions}

Employing the SERVQUAL model and Fuzzy Delphi Method, this study developed a 28-item questionnaire with five constructs for experts to rate the importance of each item. The analysis generated 17 items that were perceived by experts as crucial in evaluating care quality. SAM and FAHP were then employed to synthesize the opinions of experts and residents' family members, which created the final list of indicators. The results ranked indicators as follows. The construct to which each belongs is shown in parentheses:

1. Staffs can respond promptly to any incident (Responsiveness).
2. In any dispute involving care, the institution would give top priority to safeguarding the rights and dignities of residents (Empathy).

3. Long-term care institution should keep accurate records (Reliability).

4. Staffs are trustworthy, letting residents feel secure (Assurance).

5. Services provided by the long-term care institution are in congruence with the needs of their residents (Empathy).

6. When a resident needs assistance, staffs can be called upon immediately (Responsiveness).

7. Staffs provide care differentially by attending to the different needs of residents (Empathy).

These indicators pertained to the four constructs of responsiveness, empathy, reliability, and assurance. They were all important measures of quality care as identified by experts and residents' family members. The first two constructs were even more crucial than the others, given that more indicators fell into their categories. Indicators under discussion were in congruence with findings from a number of studies. For instance, Finnema et al. (2001) found that frequent contacts and communication with consumers was perceived as one of the safeguards of quality care in nursing homes. Frequent communication increased the chances of resident needs being attended to and of care rendered being tailored to individual needs. Similarly, Rantz et al. (1999) proposed an individualized care arrangement that, among other things, would serve to boost care quality. 
Individualized care requires staffs to differentiate care arrangement and be responsive to individual needs. Lanza (1997) maintained that nursing home staff responsiveness, individualized care, empathy, and respect for the dignity of elderly residents were all conducive to residents' autonomy, personal identity, and an intact self-concept.

Unfortunately, the current conditions of many community-based long-term care institutions seem to run counter to those demands. One of the most mentioned problems of institutional care is its reduction of personal autonomy through collectivization. Although collectivization makes management of care more efficient and cost effective, it denies residents of their quest for personal identity, autonomy, and care tailored to individual needs. Under the pressure of providing care within limited budgets, collectiveness has taken a front seat, while empathy, respect, responsiveness, and reliability care provision have all taken a back seat. A shortage of health care aides and an over-reliance on foreign workers have compounded problems and worked to exacerbate care conditions. Residents have difficultly communicating with foreign workers, who are typically not proficient in Taiwanese or Mandarin. Care rendered under such conditions is even further removed from quality care with empathy, responsiveness reliability, and assurance.

This study concluded that an overhaul in the institutional care system is urgent. One of the indispensable steps to an overhaul lies in the strengthening of inspection from within and without. Long-term care providers and administrators may impose self-inspection to ensure care quality. From without, frequent official inspections may work to enhance quality further. Consumer reports on care quality may also help raise consciousness of current as well as potential users in exercising their right by carefully choosing a home. All of these steps to improve care quality cannot work without a well-refined set of indicators. This study presented itself as part of the effort to improve evaluative tools available to assess nursing home care quality. Further studies by applying the indictors generated in this study are needed to secure its applications and utilization.

\section{References}

Buckley, J. J. (1985). Fuzzy hierarchical analysis. Fuzzy Sets and Systems, 17, 233-247.

Chiou, C. J., Yang, M. S., \& Chen, C. H. (2004). Vision of long term care: A family-centered geriatric care. The Journal of Long Term Care, 7(4), 386-398.
Chou, S. M., Chen, T. F., Woodard, B., \& Yen, M. F. (2005). Using SERVQUAL to evaluate quality disconfirmation of nursing service in Taiwan. The Journal of Nursing Research, 13(2), 75-84.

Ciou, W. J., Chang, Y. T., Hung, Y. N., \& Tam, S. C. (2006). Hospital staff and responsibility center system: Using the AHP method. Taiwan Journal of Public Health, 25(1), 49-57.

Council for Economic Planning and Development, Executive Yuan. (2005, October 5). Medical and health care service provider. Retrieved May 4, 2007, from http://www .cepd.gov.tw/upload/SECT/Smile/SmileResults/ 2@172573.73630956485@.ppt

Deming, W. E. (1982). Quality productivity and competitive position. Cambridge, MA: MIT press.

Duffy, J., Duffy, M., \& Kilbourne, W. E. (2001). A comparative study of resident, family, and administrator expectations for service quality in nursing homes. Health Care Management Review, 26(3), 75-85.

Finnema, E., Lange, J., Dröes, R., Ribbe, M., \& Tilburg, W. (2001). The quality of nursing home care: Do the opinions of family members change after implementation of emotion-oriented care? Journal of Advanced Nursing, 35(5), 728-740.

Hsu, H. M., \& Chen, C. T. (1996). Aggregation of fuzzy opinions under group decision making. Fuzzy Sets and Systems, 79(3), 279-285.

Hsu, T. H. (1998). Fuzzy Delphi analytic hierarchy process. Journal of Fuzzy System, 4(1), 59-72.

Hung, L. L., \& Kao, S. F. (2004). Health building in longterm care agency: The concept and strategy. The Journal of Long Term Care, 8(3), 321-326.

Institute of Medicine, Committee on nursing home regulation. (1986). Improving the quality of care in nursing homes. Washington, DC: National Academy Press.

Lanza, S. (1997). Essentials for the activity professional in long-term care. New York: Delmar Publication.

Li, S. D. (1999). Health care of the elderly and human right. Community Development Journal, 86, 149155.

Li, S. L., Pong, S. H., \& Wu, C. M. (2004). Discussion the impact of being relocated to institutional care for the elderly. The Journal of Long Term Care, 7(4), 371385.

Noorderhaven, N. (1995). Strategic decision making. Workingham, UK: Addison-Wesley.

Parasuraman, A., Zeithaml, V. A., \& Berry, L. L. (1985). A conceptual model of service quality and its implications for future research. Journal of Marketing, 49(3), 41-50. 
Parasuraman, A., Zeithaml, V. A., \& Berry, L. L. (1988). SERVQUAL: A multiple-item scale for measuring consumer perceptions of service quality. Journal of Retailing, 64(1), 13-40.

Rantz, M. J., Zwygart-Stauffacher, M., \& Flesner, M. (2005). Advances in measuring quality care in nursing homes: A new tool for providers, consumers, regulators, and researchers. Journal of Nursing Care Quality, 20(4), 293-296.

Rantz, M. J., Zwygart-Stauffacher, M., Popejoy, L., Grando, V. T., Mehr, D. R., Hicks, L. L., et al. (1999). Nursing home care quality: A multidimensional theoretical model integrating the views of consumers and providers. Journal of Nursing Care Quality, 14(1), 16-37.

Robbins, S. P. (1994). Management. Upper Saddle River, NJ: Prentice Hall.
Saaty, T. L. (1977). A scaling method for priorities in hierarchical structures. Journal of Mathematical Psychology, 15, 234-281.

Saaty, T. L. (1980). The analytic hierarchy process. New York: McGraw-Hill.

Wang, W. F., \& Chen, Y. M. (2004). Family experiences of placing the elderly in long-term care facilities. The Journal of Long Term Care, 8(3), 327-344.

Wu, S. C., \& Chuang, K. Y. (2001). Aging in place: The direction of Taiwan long-term care policy in the 21st century. Taiwan Journal of Public Health, 20(3), 192201.

Wu, S. J., \& Lin, H. S. (1999). Incidence of and predictors for chronic disabilities of daily living among the elderly in Taiwan. Journal of American Geriatrics Society, 47, 1082-1086. 


\title{
長期照護機構服務品質準則之研究
}

\author{
王文良 張宏哲* 劉安琪** 陳毓文***
}

摘 要：本研究的目的在建立影響長期照護機構服務品質的準則。本研究分成兩部份：首先, 研究者利用 SERVQUAL 模式以及模糊德爾菲法 (Fuzzy Delphi Method) 建立量測長 期照護機構服務品質的準則, 本研究第一階段針對專家發出 200 份問卷, 回收 89 份, 有效問卷 77 份，做爲進一步分析之用；接著利用多準則決策分析法，找出在進行服 務品質規劃時這些準則的重要性程度。第二階段再發出 200 份問卷, 對象除了專家 之外, 還包括住民的家屬, 最後回收 78 份, 有效問卷共 74 份。經過 SERVQUAL model 分析的結果顯示：在 SERVQUAL 模式的 5 個構面下, 本研究所得到的 28 個準則中, 共 17 個準則屬於長期照護服務品質的指標, 其中又以反應性及關懷性這兩個構面之 下的準則是長期照護機構服務最迫切需要改善的項目。

關鍵詞： 長期照護機構、服務品質、SERVQUAL 模式、多準則決策分析。

中華大學資訊管理學系助理教授 *國立台北護理學院長期照護研究所助理教授 $* *$ 育達商業技術學院 行銷與流通管理學系講師＊**國立台灣大學社會工作學系副教授

受文日期：96 年 2 月 1 日 修改日期：96 年 5 月 14 日 接受刊載 : 96 年 9 月 17 日 通訊作者地址 : 王文良 30012 新竹市香山區五福路二段 707 號 